\title{
Risk factors of contrast-associated acute kidney injury in spanish intensive care patients: preliminary results of the nefrocon study
}

\author{
S Mas-Font ${ }^{1 *}$, C Gómez-Gonzalez², D Herrera-Rojas ${ }^{3}$, M Herrera-Gutierrez $^{4}$, L Del Baño-Aledo ${ }^{5}$, MJ Broch-Porcar ${ }^{6}$, \\ E Moreno-Clari ${ }^{7}$
}

From ESICM LIVES 2015

Berlin, Germany. 3-7 October 2015

\section{Objectives}

It is essential to Know the profile of the patients at risk of developing contrast-associated acute kidney injury (CA-AKI) in order to define strategies for prevention. The aim of this study is to determine risk factors related to contrast-associated acute kidney injury in critical patients.

\section{Methods}

We performed a prospective multi-center study, in 34 Spanish ICU, covering the period from 15 December 2012 to 15 March 2013. During this study period, we included 1035 patients, all of them undergoing a radiographic examination or a coronary angiography with administration of parenteral iodinated contrast media. We excluded patients with incomplete data or renal replacement at the time of the study, being finally 1012 patientes. We defined CA-AKI as an increase of serum creatinine $\geq 0,5 \mathrm{mg} / \mathrm{dl}$, or $\geq 50 \%$ from baseline, assessed 48-72 hours after the procedure. We performed the analysis using multiple logistic regression with CA-AKI as dependent variable using the R 3.1.2 software for OsX. We included in the analysis the variables with $\mathrm{p}<0,1$ in the univariate tests and those collected in the literature as related to the CA-AKI.

\section{Results}

We find that the type of patient $(\mathrm{p}<0,001)$, age $(\mathrm{p}<$ $0,005)$, presence of risk background $(\mathrm{p}<0,05)$ [ cirrhosis $(\mathrm{p}<0,003)$, heart failure $(\mathrm{p}<0,005)$, previous transplant $(\mathrm{p}<0,05)$, chronic kidney disease stage II-V $(p<0,001)]$, baseline serum creatinine $(p<0,001)$, APACHE II $(\mathrm{p}<0,001)$, diuretics $(\mathrm{p}<0,001)$, vasoactive therapy $(\mathrm{p}<0,001)$ and shock $(\mathrm{p}<0,001)$, were related to CA-AKI. CA-AKI was less frequent in coronary angiography $(7,9 \%)$ than in contrast enhanced TC $(16,1 \%)$ or other radiographic examinations $(15,9 \%, \mathrm{p}<0,001)$. Higher hemoglobin concentration $(\mathrm{p}<0,001)$ at time of contrast administration was a protective factor. Diabetes, hypertension, use of metformin, and the type and volume of contrast are not shown as risk factors. Neither the application of preventive measures.

\section{Conclusions}

In our cohort, severity of illness, previous kidney function and use of diuretics were the most relevant factors in relation to the development of CA-AKI, however, high levels of haemoglobin were as protectors, presenting lower incidence of CA-AKI.

Table 1. Multivariate analysis (test Hosmer- Lemeshow $\mathbf{p}$ 0,7

\begin{tabular}{lllll}
\hline & Coefficient & $\mathbf{p}$ & OR & $\mathbf{9 5 \%} \mathbf{C l}$ \\
\hline Apache II &, 029 &, 045 & 1,030 & $1,001-1,060$ \\
\hline Baseline serum creatinine &, 389 &, 067 & 1,476 & $, 973-2,238$ \\
\hline Diuretics &, 670 &, 003 & 1,955 & $1,247-3,065$ \\
\hline Shock &, 969 &, 000 & 2,636 & $1,634-4,253$ \\
\hline Hemoglobin &,- 114 &, 011 &, 892 &, $817-, 974$ \\
\hline
\end{tabular}




\section{Authors' details}

${ }^{1}$ Hospital General Universitario de Castellón, Intensive Care Unit, Castellón, Spain. ${ }^{2}$ Hospital Infanta Luisa, Intensive Care Unit, Sevilla, Spain. ${ }^{3}$ Hospital Universitario de Valme, Intensive Care Unit, Sevilla, Spain. ${ }^{4}$ Complejo Universitario Carlos Haya, Intensive Care Unit, Málaga, Spain. ${ }^{5}$ Hospita Morales Meseguer, Intensive Care Unit, Murcia, Spain. ${ }^{6}$ Hospital Universitari Politècnic La Fe, Intensive Care Unit, Valencia, Spain. ${ }^{7}$ Hospital Universitario General de Castellón, Intensive Care Unit, Castellón, Spain.

Published: 1 October 2015

doi:10.1186/2197-425X-3-S1-A53

Cite this article as: Mas-Font et al:: Risk factors of contrast-associated acute kidney injury in spanish intensive care patients: preliminary results of the nefrocon study. Intensive Care Medicine Experimental 2015 3(Suppl 1):A53.

\section{Submit your manuscript to a SpringerOpen ${ }^{\circ}$ journal and benefit from:}

- Convenient online submission

- Rigorous peer review

- Immediate publication on acceptance

- Open access: articles freely available online

- High visibility within the field

- Retaining the copyright to your article

Submit your next manuscript at $\gg$ springeropen.com 